\title{
IN MEMORIAM EMERITUS PROFESSOR ARNE LEPP: A LIFE DEDICATED TO MEDICINE
}

\section{November 1928 - 23 October 2018}

Emeritus Professor Arne Lepp, a valued colleague and highly honoured Professor of Anatomy at the University of Tartu, passed away somewhat more than a month before his 90th birthday.

Arne Lepp was born to a family of intellectuals in Viljandi, Estonia. He acquired his general education at Viljandi 2nd Secondary School. In 1947, he entered the Department of Therapy at the Faculty of Medicine at the University of Tartu. In the same year, A. Lepp was employed as an assistant at the Chair of Anatomy. From 1969, he continued working as a senior lecturer and from 1973 as an associate professor. He described how he chose anatomy as his speciality: "It was greatly accidental that I happened to take up anatomy. Everything began with being the students' trade union representative. A fellow student had problems and was in danger of expulsion from the university. It was customary in the post-war years to arrange a hearing at the university, and the Assistant Dean of the Faculty of Medicine summoned the Young Communist League (YCL) organiser and trade union representative and appointed me as defender. The prosecutor was the YCL organiser, who recommended to expel the student, as could be expected. At first, I agreed with the prosecutor but later made the collective responsible, as they had not guided the fellow student. Thus, the student was saved from expulsion, and this was the main reason why I was elected head of the class after that. In my last year of studies, two weeks before appointment to posts, six male students were called to the Dean's Office. They were recommended to become members of the Young Communist League. I was offered the position of head physician in a hospital in the capital. I did not join the YCL, and thus, I openly made a political decision. I did not even want that position; I had always wanted to become a doctor in my home town, but that year, there were no vacancies there. As my academic achievements were the best, I was offered various positions at the university. I wondered which post would be the best for later continuation of my work as a physician at Vil- 
jandi hospital. I chose anatomy as a springboard. There was a group of active studious young lecturers at the Chair of Anatomy; all of us learned our speciality in depth, argued about various problems of anatomy and became increasingly engaged in research. Soon the Assistant Dean offered me an opportunity to take up postgraduate studies of anatomy in Moscow. So it happened. I had to take ten pass-fail evaluations before being allowed to the exam. My further fate was set by the first evaluation (about the skeleton and locomotor system), which also remained the last. Despite my supervisor's "efforts", I got a maximum grade for all the answers."

From 1959-1962, A. Lepp attended postgraduate studies at Moscow 1st Medical Institute. In 1971, he defended his Candidate's dissertation Main characteristics of lung segments and subsegments based on their variants in humans and some animals. Studies of segments accelerated in the 1940s due to developments in lung surgery - advancement of diagnostic and treatment methods. Earlier, the whole lung was removed, but later, only smaller parts were removed in the case of some pathologies. The need developed to distinguish smaller structural units than lobes - segments - for the purposes of topic diagnostics and treatment. Subsegments are the criterion and content of the essence of segments - the main feature on which the variants of segments depend. Prof. Lepp recalls: "Prof. D. Zhdanov gave me a theme on segments - not much was known about them and their lymphatic drainage at that time. The theme was Efferent lymphatic vessels in lung segments. The aim was to identify regional lymph nodes corresponding to segments. The research method was intrapleural injection of dye dissolved in a mixture of ether and chloroform. In retrospect, it can be said that the lymph system of an adult's pleura fills very badly by injection. Nonetheless, I achieved better results than several earlier researchers of the lung lymphatic system. The main aim of the study, however, remained greatly unfulfilled, as in the case of intrapleural injections these lymphatic vessels are filled which run in the connective tissue between the structural units of the lungs together with veins. The lymphatic vessels inside the structural units in the connective tissue surrounding the bronchi and the arteries, however, are not filled. As for segments - I was probably among the first in Moscow to make lung segments filled with coloured gelatine, which were demonstrated at hospitals." Together with Assoc. Prof. E. Lepp, A. Lepp elaborated the methodology of corrosion studies, which was novel for the time. This enabled him to involve the young staff of the Chair into studies of segmental composition of parenchymal organs and architectonics of blood vessels. Using the same method, the first post-war dissertations on morphology were defended in Tartu. 


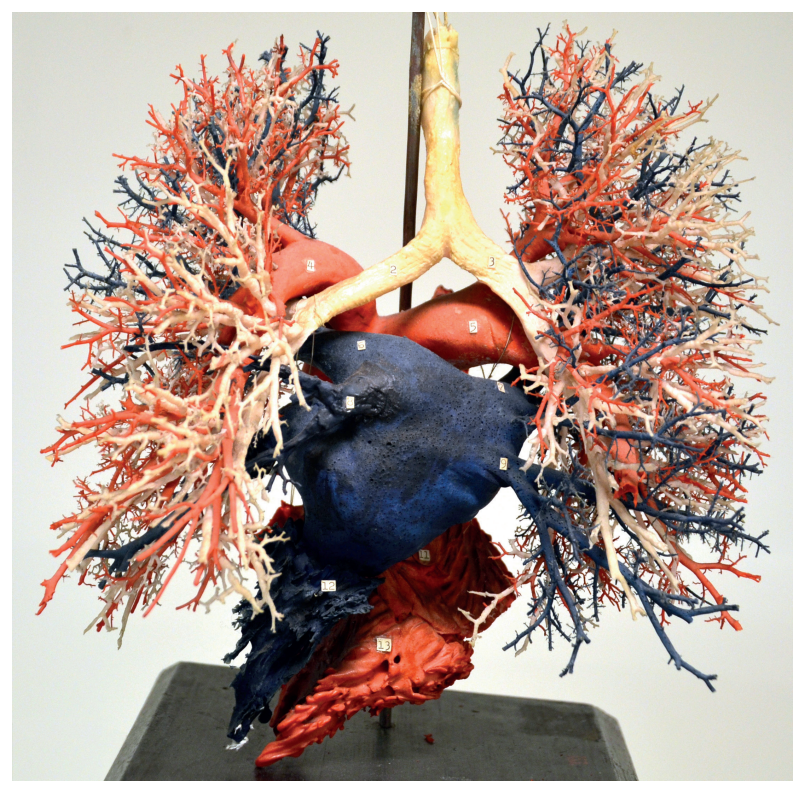

Figure 1. Corrosion specimen of lungs, filled through the heart - arteries red, veins - blue, bronchi - pink.

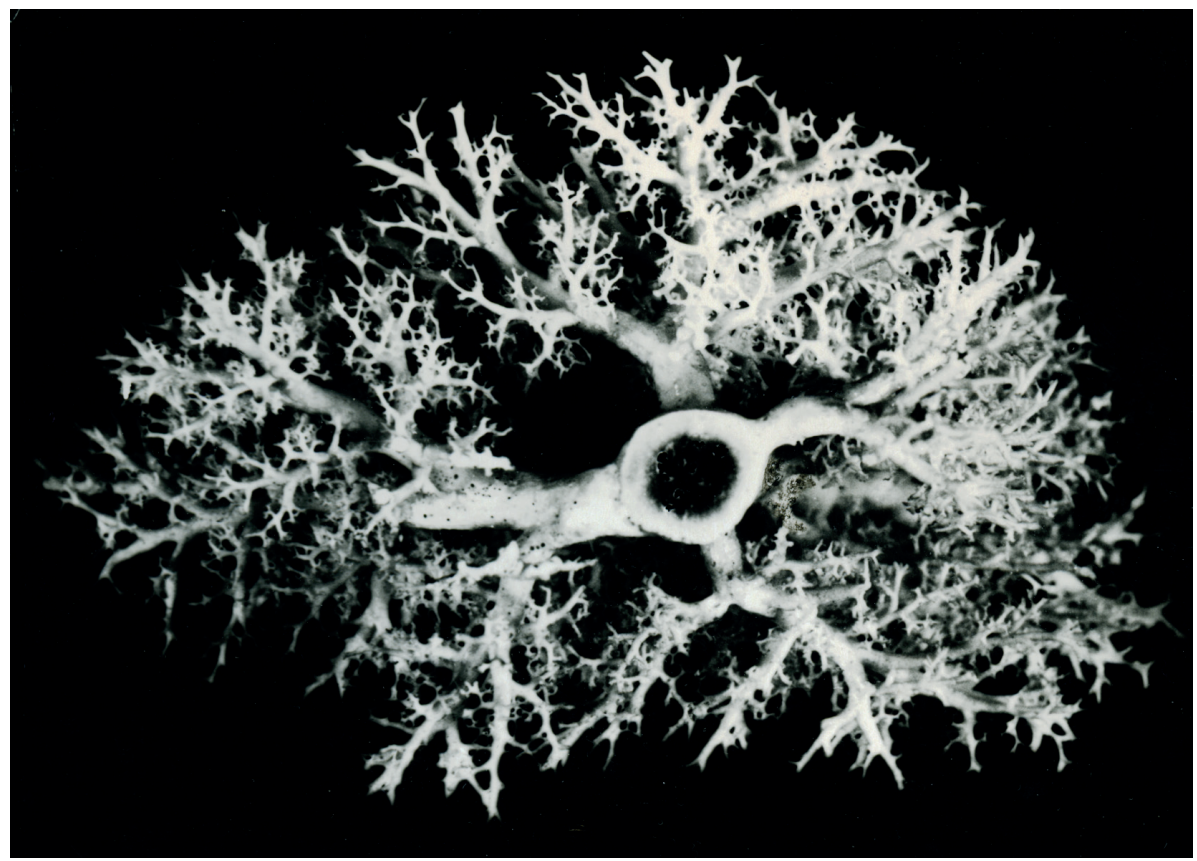

Figure 2. Four-directional (not two-directional) side branches of domestic pig's trunk bronchus. Photo by A. Lepp. 
The results of anatomical research (segmental composition of the kidney and the liver) achieved in Tartu in that period deserve attention even today and have been quoted in several monographs (Gray 1980, Бурых 2000). In his numerous research papers (103) dealing with the internal structure of the lungs and the liver, functional anatomy of blood and lymphatic vessels, morphoadaptation and regeneration of parenchymal organs, Prof. A. Lepp has striven for substantiated connections and solutions.

The supervisor of his doctoral thesis, Prof. D. Zhdanov, being convinced of A. Lepp's excellent knowledge of anatomy, asked him to write a review of the Hungarian author T. Donath's dictionary Erläuterndes anatomisches Wörterbuch on behalf of the Society of Anatomists, Histologists and Embryologists of the Soviet Union. There was an intention to publish the book in Russian translation. A. Lepp was asked to give an assessment if the book should be published in Russian. After submitting the review, A. Lepp, in cooperation with Prof. G. Satyukova, was appointed the editor of the Russian dictionary. No such dictionary had been published in the USSR before. Two hundred pages of additions and corrections were made to it. The book was published in Budapest in 1964. Throughout his life, A. Lepp was devoted to using accurate Estonian and Latin terminology in medicine. He was the author of numerous articles on morphology in the Estonian Encyclopaedia.

After post-graduate studies, A. Lepp was offered an assistant's post in Moscow, but because of unfinished tasks, he returned to Tartu. In 1989, A. Lepp became Head of the Chair of Anatomy. In 1992, he was elected Professor of Anatomy.

Arne Lepp's life's work was teaching of several generations of physicians at the University of Tartu, systematisation of Estonian medical terminology and publishing of study literature. His impact on medical education has been significant - he was engaged in teaching at the University of Tartu for more than 60 years. Under his supervision, medical students acquired the knowledge base in anatomy, and the formation of their views on medicine was founded on his knowledge and skills. The will to pass on his knowledge was one of Arne Lepp's characteristics. He was the editor of the textbook in Estonian, Human Anatomy I (Inimese anatoomia I, 1974), which remained a timeless study material for medical students for decades. In the following years, A. Lepp published about ten study aids in Estonian with his own illustrations. As emeritus professor, A. Lepp continued dedicated work on study materials on anatomy; in 2013 he published the revised and updated version of the first part of his textbook of anatomy and continued work on the second part. 


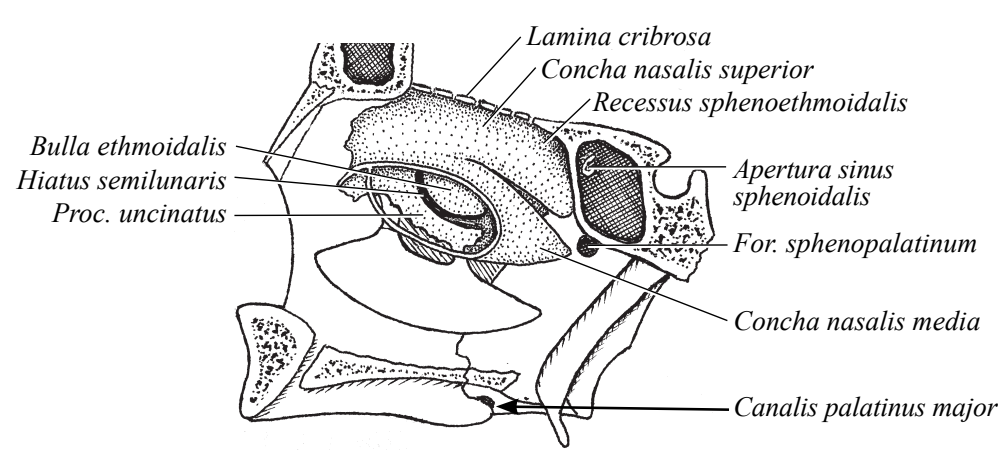

Figure 3. A. Lepp illustrated his study materials himself: in the figure - schematic construction of the lateral wall of the nasal cavity. Closure of the opening of the maxillary sinus from the front, back, below and above by the lacrimal bone, palatine bone, inferior nasal concha and ethmoid bone. The only connection between the maxillary sinus and the nasal cavity is hiatus semilunaris which is located between proc. uncinatus and bulla ethmoidalis of the ethmoid bone. To make it visible, the frontal part of central nasal concha has been removed in the figure.

Having begun in the difficult material situation of the post-war years, he lived until the high-tech present. The conditions changed, but as a person, he retained his essence regardless of times - he loved anatomy, his students and science.

Arne Lepp was a member of the Estonian Morphology Association and the International Federation of Associations of Anatomists (IFAA). For teaching and research, he was awarded the A. Rauber memorial medal, the large medal of the University of Tartu and the 1st class Order of the Estonian Red Cross.

Liina Pärnsalu, Aade Liigant, Kersti Kokk, Elle Põldoja 